\title{
〔10１1〕イオン交換体に関する研究
}

第 13 報 アニオン交換樹脂と酸性染料とのイオン交換反応

(1959 年 7 月 1 日受理)

$$
\text { 芦并 包義* }
$$

\footnotetext{
要旨強㙋基性㧍よび弱㙁基性アニオン交換樹脂と酸性染料とのイオン交換反応の速度ならびに平 衡を調へた。樹脂粒径 $P(\mathrm{~mm})$ と交換量 $E(\mathrm{meq} / \mathrm{g})$ との関保を求めると, $\log E$ と $\log P$ とは直線関係にあ り，かつ $\log E$ の值は経時的に增大することから樹脂表面のみならず榯脂相においててイオン交換反応がお こっていることが認められた。次にイオン交換速度はカチオン交換樹脂の場合と同様に, $E=k t^{n}(E$ : 交換量, $t:$ 接触時間， $k, n$, はそれぞれ定数) が成立し，また反応速度は温度によって著しく影響される。その他，弱 塩基性樹脂による染料の吸着量は塩型樹脂のみ有効であって遊離塩基型樹脂の場合はきわめて少ないこと、ア ルコール溶液中における染料イオンの吸着は水溶液の埸合に比へてきわめて小さいこと，などを認めた。最後 にイオン交換平衡を調べ，Freundlich の等温吸着式がよく適合することを見出した。
}

1. 緒 $\overline{\overline{\bar{\sigma}}}$

前報”に引続いてアニオン交換樹脂と酸性染料とのイ ナン交換反応を調べた。アニオン交換樹脂の遊雔塩基型 を $\mathrm{ROH}$, 塩酸程型を $\mathrm{RCl}$ で表わし, 杂粘ィオンを $\mathrm{D}$ ， 酸性染料を $\mathrm{NaD}$ とすれば揭題の反应は次の二つの式で 示される。

$$
\begin{aligned}
\mathrm{RCl}+\mathrm{NaD} & =\mathrm{RD}+\mathrm{NaCl} \\
\mathrm{ROH}+\mathrm{NaD} & =\mathrm{RD}+\mathrm{NaOH}
\end{aligned}
$$

さて, 強塩基性樹脂においては $\mathrm{RCl}$ 型も $\mathrm{ROH}$ 型も ともに解䧳性が大きく, 膨潤容積の変化も少ないので, 前報に打りる強酸型樹脂の挙動とほぼ同様の挙動を示す であろうと考えられる。したがって强塩基性樹脂は $\mathrm{RCl}$ 型についてのみ実験し, 弱塩基性樹脂は $\mathrm{RCl}$ 型および $\mathrm{ROH}$ 型の欢方について実験した。

なお樹脂は Amberlite IRA 400, IRA411 および IR 4B を使用し，染料はアシット゚パイナレットを選んだ。 実験方法湔報と全く同样である。

\section{2. 粒径と交換量}

樹脂䊉径 $(P \mathrm{~mm})$ と交換量 $(E \mathrm{meq} / \mathrm{g})$ 上の関倸在求め て第 1 図を得た。この場台も前報”の場台と同栚に $\log$ $E$ と $\log P$ とが淔楾関倸にあって，しかも $\log E$ が径 時的に増大して漸次平衡値に近つく様子が見受けられ る。したがってアニオン交換樹脂もまた樹脂表面反忍に 引続いて樹脂相における反店が起っていると考えられ る。

\section{3. 弱嗢基性樹脂の $\mathbf{R C l}$ 型と $\mathbf{R O H}$ 型との 交換速度の相違}

弱塩基性樹脂である Amberlite IR4B に対するアシ

* 日清紡績株式会社科学研究所(東京都足立区栗原町 1090)

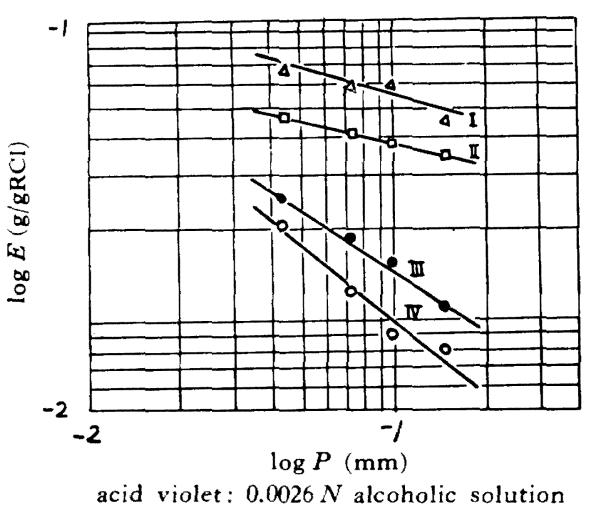

I：11日, II : 7日, III : 7日, IV : 1 時間

第 1 図 Amberlite IRA 400 の粒径 $(P)$ と 交換量 $(E)$ との関係

ッドパイオレットの交換速度は第 2 図に示すごとくで あって，前報で述へた実験式がよく適合する。すなわち 交換量を $E(\mathrm{meq} / \mathrm{g})$ ，接触時間を $\boldsymbol{t}(\mathrm{hr}) k$ および $n$ をそ れぞれ定数とすればその交換速度は第 3 式で示される。

$$
E=k t^{n}
$$

したがって $k$ (主として樹脂表面の交換速度) および $n$ (主として樹脂相における交換速度) を比較して交換反応 の特徵を調べることとした。第 2 図から水めた $k$ および $n$ の偭は第 1 表 No. 1〜2 に示した。 $\mathrm{ROH}$ と $\mathrm{RCl}$ との举 動の相違は顕著であって, $\mathrm{ROH}$ 型樹脂の父換量は 10 時 問以前においては無視できるほど小さく，その $k$ は $\mathrm{RCl}$ 型の 1 万分の 1 程度であるが, 10 時問以後になると顕著

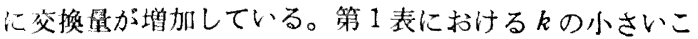
とは弱塩基性樹脂の非解踓性 ${ }^{3 a)}$ に基くものと考えられ， また $n$ の大きいことは交換量の增加に伴って交換基の解

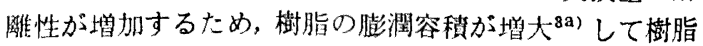
内反応が容易となるからであろらと考えられる。 
第 1 表 $k$ と $n$ の值

\begin{tabular}{|c|c|c|c|c|c|c|c|c|c|}
\hline No. & 樹 脂 & 名 & 型 & 温度 & $\begin{array}{l}\begin{array}{l}\text { 粒 度 } \\
\text { (mesh) }\end{array}\end{array}$ & 溶＼cjkstart媒 & $k$ & $n$ & 備 考 \\
\hline 1 & Amberlite & IR4B & $\mathrm{RCl}$ & 室温 & $100 \sim 110$ & water & 0.10 & 0.55 & Fig. 2 \\
\hline 2 & " & IR4B & $\mathrm{ROH}$ & 室温 & $100 \sim 110$ & water & 0.000028 & 1.41 & Fig. 2 \\
\hline 3 & " & IRA 400 & $\mathrm{RCl}$ & $100^{\circ} \mathrm{C}$ & $200 \sim 230$ & water & 0.044 & 0.35 & Fig. 3 \\
\hline 4 & " & IRA400 & $\mathrm{RCl}$ & $100^{\circ} \mathrm{C}$ & $100 \sim 110$ & water & 0.039 & 0.35 & Fig. 3 \\
\hline 5 & $"$ & IRA400 & $\mathrm{RCl}$ & 室温 & $200 \sim 230$ & water & 0.028 & 0.17 & Fig. 3 \\
\hline 6 & " & IRA400 & $\mathrm{RCl}$ & 室温 & $100 \sim 110$ & water & 0.010 & 0.26 & Fig. 3 \\
\hline 7 & $"$ & IRA400 & $\mathrm{RCl}$ & 室温 & $300 \sim 325$ & alcohol & 0.018 & 0.23 & Fig. 4 \\
\hline 8 & $"$ & IRA400 & $\mathrm{RCl}$ & 室温 & $200 \sim 230$ & alcohol & 0.011 & 0.28 & Fig. 4 \\
\hline 9 & $"$ & IRA400 & $\mathrm{RCl}$ & 室温 & $150 \sim 160$ & alcohol & 0.0080 & 0.34 & Fig. 4 \\
\hline 10 & " & IRA400 & $\mathrm{RCl}$ & 室温 & $100 \sim 110$ & alcohol & 0.0046 & 0.41 & Fig. 4 \\
\hline 11 & " & IR4B & $\mathrm{RCl}$ & 室温 & $300 \sim 325$ & alcohol & 0.0094 & 0.23 & Fig. 5 \\
\hline 12 & " & IR4B & $\mathrm{RCl}$ & 室温 & $100 \sim 110$ & alcohol & 0.0056 & 0.26 & Fig. 5 \\
\hline
\end{tabular}

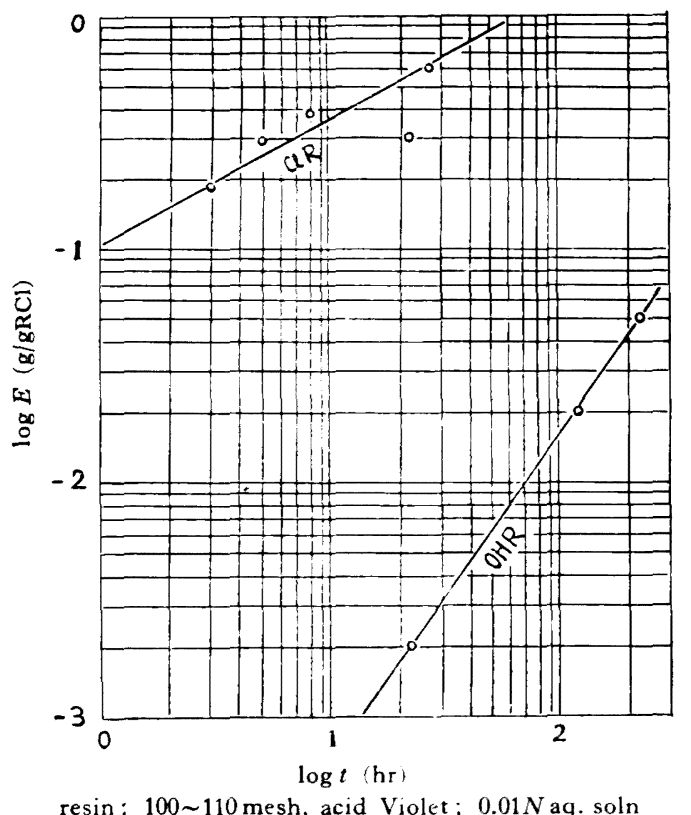

第 2 図Amberlite IR4B こよるAcid Violet の吸着

\section{4. 反応温度の影餐}

無機イオンに対するイオン交換の速度はきわめて早 く,イオン反応の特長を示すことが知られている ${ }^{8 \mathrm{~b})}$ 。染 料イオンのような大きいイオンに対するイオン交換の速 度は樹脂相における拡散速度によって大きな制約を受 け，しかもその挔散速度は当然温度によって影響を受け るはずである。

第3図はその影響の程度を調へるるめに Amberlite IRA 400 を用いて実験した結果であって, 第 1 表 No. 3

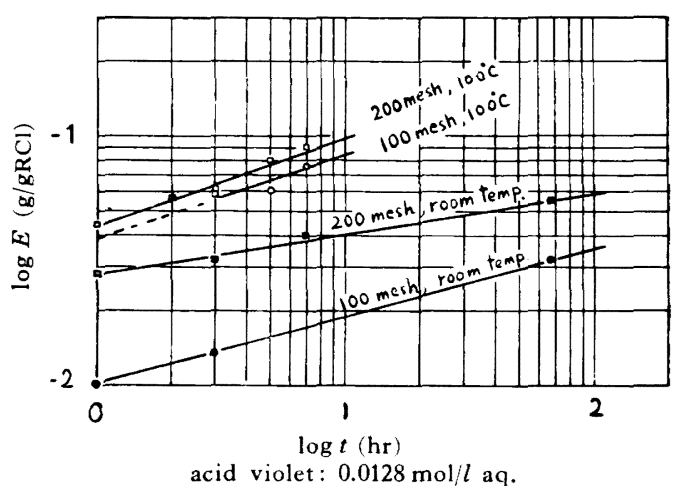

第 3 図 反応温度と交換量 (amberlite IRA 400, $\mathrm{RCl}$ 型)

〜No. 6 に $k$ およびnを示した。これらの図表に明らか なように，温度の影響はきわめて大きく，無機イオンの 場合と著しい相違を示している。なおこの実験に用いた 染料はアシッドパイナレット，役料港度は $0.0128 \mathrm{~mol} / l$, 樹脂の粒度は 100〜110メッシュおよび 200〜230メッ シュである。

\section{5．アルコール溶液における反応}

$98 \%$ アルコール溶液中における酸性染料と $\mathrm{RCl}$ 型樹 脂との反応を調へ, Amberlite IR A400 の場合を第 4 図に，Amberlite IR4B の場合を第 5 図に示し， $k$ 拉よ ぴnを第 1 表 No. 7 12 に示した。実秧方法としては風 乾した $\mathrm{RCl}$ 型樹脂 $0.50 \mathrm{~g}$ をアシッドバイオレットの $98 \%$ アルコール溶液 $(0.0026 N) 20 \mathrm{cc}$ に加え，之の濃度 变化をチタン分析によって求めた。

$k$ およぴnの值を比較すると，同一粒度の樹脂の水溶 液反応に比へて $k$ が非常に小さい。このことは $\mathrm{RCl}$ の アルコール中に㧍ける膨潤が少ないためと考えられ。 


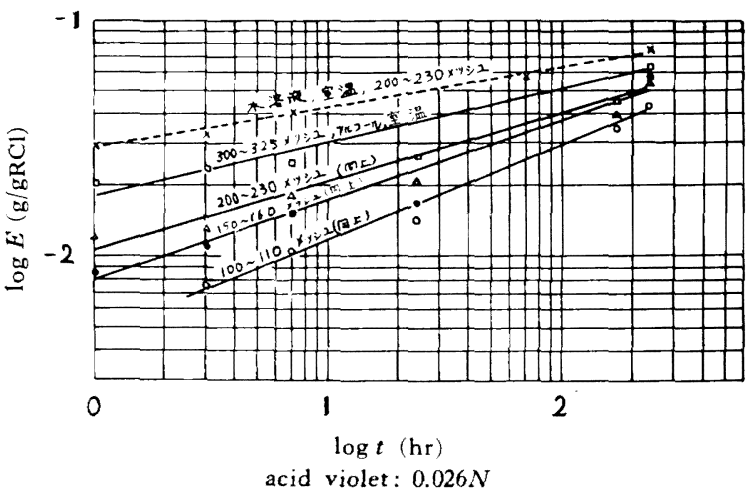

第4図アルコール溶液に㧍汁る Acid Violet Amberlite IRA400 とのイオン交換

$\mathrm{NaR}$ 型カチオン交換樹脂のアルコール溶液中に㧍ける 挙動1)上よく一致している。

\section{6. イオン交換平衡}

アニナン交換樹脂に対する染料アニオンのイオン交換 平衡を調へるるめに，150〜160メッシュの Amberlite IRA $400(\mathrm{ClR})$ および Amberlite IRA $411(\mathrm{ClR})$ を $10^{-2}$ 〜 $10^{-5} \mathrm{~mol} / l$ のアシッドバイオレット水溶液中に 15 16 日間浸漬させ, 平衡濃度を千夕ン分析によって求めた。 染料吸着量 $r(\mathrm{~g})$, 乾燥樹脂重量 $m(\mathrm{~g})$ および平衡濃度

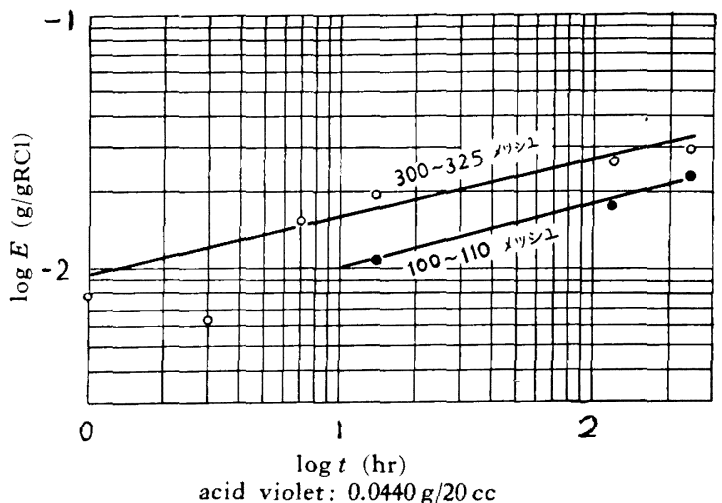

第 5 図アルコール溶液における Acid Violet と Amberlite IR4B(RCl)の交換速度

$C(\mathrm{~mol} / l)$ の関倸を示せば Amberlite IRA 400 について は第 6 図, Amberlite IRA 411 について第7図のご とくになる。

これらの図から明らかなように染料吸着量と平衡濃度 との間には Freundlich の等温吸着式

$$
x / m=a C^{n \prime}
$$

がなりたつ。また眓から $a$ および $n^{\prime}$ の值を算出すると 第 2 表のごとくになる。

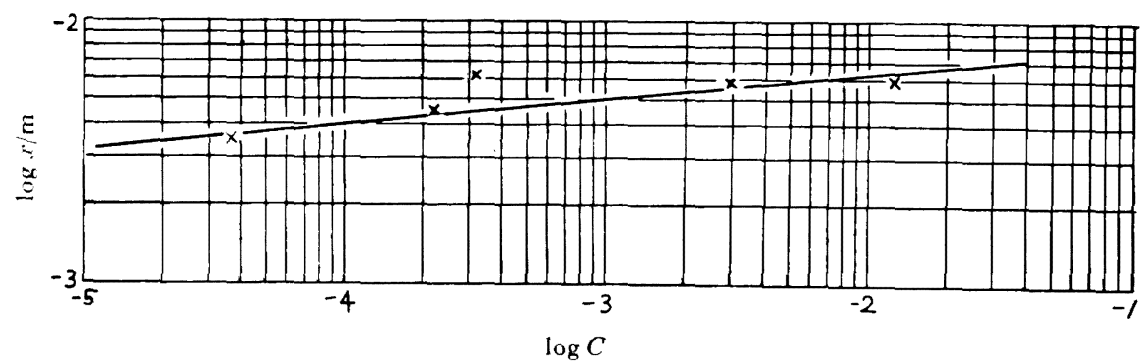

第 6 図 Amberlite IRA400 $(\mathrm{RCl})$ による Acid Violet の等温吸着線

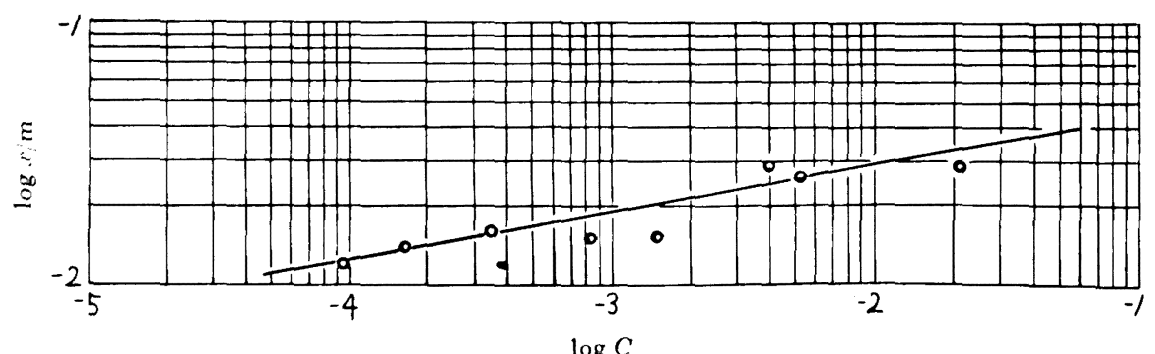

第 7 図 Amberlite IRA411 (RCl)による Acid Violetの等温吸着線 
第 2 表 $a$ 扩よび $n^{\prime}$ の值

樹 脂
Amberlite IRA400 $(\mathrm{RCl})$
Amberlite IRA411 $(\mathrm{RCl})$

\begin{tabular}{c|c|c|c} 
染 料 & 時間(日) & $a \times 10^{3}$ & $n^{\prime}$ \\
\hline Acid Violet & 15 & 3.2 & 0.10 \\
" & 16 & 82 & 0.19
\end{tabular}

付 記：こD研究:は保土谷化学工業株式会社研究所にお いて行なったものである。この研究にあたり, 種々ご援助をい ただいた伡藤久之博士，鈴木三男博士，および熱心に助力され た西村正栄理学士に対して扔礼申し上げる。

\title{
Studies on the Ion Exchangers
}

\author{
XIII. Ion Exchange Reaction of Anion Exchange Resins \\ with an Acidic Dye
}

\section{By Kaneyoshi Ashida}

\begin{abstract}
The rate and equilibrium of ion exchange between anion exchange resins and an acidic dye, e.g., acid violet, are investigated. Results obtained are shown as follows; (a) $\log E$ is in the linear relation with $\log P$, where $E$ is the amount of ion exchange and $P$ is the diameter of resin particle. (b) $\log E$ increases with the elapse of time, and this phenomena indicate ion exchange reaction in the resin phase. (c) The rate of ion exchange follows to the equation

$$
E=k t^{n}
$$
\end{abstract}

where $E, t, k$ and $n$ are amount of ion exchange, reaction time, and constants respectively. (d) The rate of ion exchange is influenced by the reaction temperature. (e) Amount of ion exchange of anion exchange resin with an acidic dye in alcoholic solution is very small. (f) Ion exchange equilibrium between ion exchange resin and acid violet is represented by Freundlich type of absorption isotherm.

第 14 報スルホン化フェノールとホルムアルデヒドとの酸接触重縮合 反応における脱スルホン酸基反応

(1959 年 7 月 21 日受理)

$$
\text { 芦田包義 }
$$

\footnotetext{
要 旨 スルホン化フェノール・ホルムアルデヒド樹脂の生成過程に㧍汁る脱スルホン酸基反応の諸原 因について研究を行なった。すなわち、。ーまたは p-フェノールスルホン酸, あるいはスルホン化フェノール. ホルムアルデヒド楜脂を塩酸，ホルムアルデヒドの酸性水溶液，2，6-ジメチロール 液などとそれぞれ種々の条件下反店させた。その結果, 脱スルホン酸基反応は (a) 酸接触加水分解反応と (b) メチロールカチオンおよび種々のメチレンカチオンによるカチオノイド圆換反応とによって起り，特に後者の 反応が脱スルホン酸基反㥦の主因であることを見出した。
}

\section{1. 緒言}

フェノールのスルホン化物(スルホン化フェノール; p-フェノールスルホン酸のみならず o-フェノールスル ホン酸も若干含まれている, PS と略記)とホルムアルデ ヒドとの重縮合物 (PS 樹脂と略記) の合成方法を大別す ると酸性重縮合法とアルカリ性重縮合法とに分けられ, 両法の得失を既往の文献に基いて整理すると第 1 表のご とくになる。

すなわち, 酸性重縮合法ではスルホン酸基の䧻脱が大

\begin{tabular}{|c|c|c|c|}
\hline 項 & 目 & 酸性重縮合法 & $\begin{array}{c}\text { アルカリ性 } \\
\text { 重縮合法 }\end{array}$ \\
\hline \multicolumn{2}{|c|}{ スルホン酸基の離脱 } & 大 & 小 \\
\hline \multicolumn{2}{|c|}{ 交換容量 (meq/g) } & 小 & やや大 \\
\hline \multicolumn{2}{|c|}{ 膨潤容積（cc/g） } & 小 & 大 \\
\hline \multicolumn{2}{|c|}{ 実用交換能力 $(\mathrm{meq} / \mathrm{cc})$} & 小 & 小 \\
\hline \multicolumn{2}{|c|}{ 樹脂生成速度 } & 大 & 小 \\
\hline \multicolumn{2}{|l|}{ 硬化温度 } & 低くて良い & 高温を要す \\
\hline \multicolumn{2}{|l|}{ 原料費 } & 廉価 & やや高価 \\
\hline \multicolumn{2}{|l|}{ 工 程 } & 簡單 & やや複雑 \\
\hline
\end{tabular}

第 1 表 酸性重縮合法とアルカリ性重縮合法との比較 